\title{
Subjective expectations regarding ageing: a cross-sectional online population survey in Hungary
}

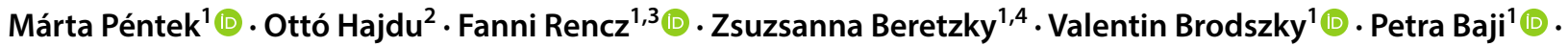 \\ Zsombor Zrubka ${ }^{1,4}$ (I) Klára Major $^{5} \cdot$ László Gulácsi $^{1} \mathbb{0}$
}

Received: 26 March 2019 / Accepted: 14 April 2019 / Published online: 20 May 2019

(c) The Author(s) 2019

\begin{abstract}
Background We aimed to investigate individuals' subjective expectations regarding health and happiness alongside their provisions on life circumstances for older ages.

Methods A cross-sectional online survey was performed involving a representative sample $(N=1000$; mean age 50.9, $\mathrm{SD}=15.4$; female 54.5\%) in Hungary. Subjective expectations on health status (EQ-5D-3L/-5L, GALI, WHO-5), happiness (0-10 VAS), employment status, care time, and forms of care for ages 60, 70, 80, and 90 were surveyed.

Results Current mean EQ-5D-5L was $0.869(\mathrm{SD}=0.164)$ and happiness was $6.7(\mathrm{SD}=2.4)$. Subjective life expectancy was $80.9(\mathrm{SD}=11.1)$, and median expected retirement age was 65. Mean expected EQ-5D-5L for ages 60/70/80/90 was $0.761 / 0.684 / 0.554 / 0.402$, and no activity limitations (GALI) were expected by $64 \% / 40 \% / 18 \% / 14 \%$, respectively. Expected happiness score was 6.8/6.7/6.2/5.7, and a decrease in mental well-being (WHO-5) was provisioned. A substantial increase in drug expenses and care time was anticipated, but only $52 \%$ thought to have extra income besides pension. The great majority expected to be helped by the family $(77 \% / 72 \% / 53 \% / 40 \%)$ if needed. Educational level, GALI, and longevity expectations were significant predictors of EQ-5D-5L expectations using a standard 5\% significance level of decision. Current happiness was major determinant of expected future happiness.

Conclusions Individuals expect a significant deterioration of health with age but only a moderate decrease in happiness. Overestimation of future activity limitations suggests a gap between statistical and subjective healthy life expectancy. The majority expects to rely on informal care in the elderly. Raise in retirement age is underestimated. Our results can be used as inputs for economic modelling of labor force participation and ageing.
\end{abstract}

Keywords Subjective expectations $\cdot$ Ageing $\cdot$ EQ-5D-5L $\cdot$ Happiness $\cdot$ Employment $\cdot$ Informal care

JEL classification I19

Electronic supplementary material The online version of this article (https://doi.org/10.1007/s10198-019-01059-w) contains supplementary material, which is available to authorized users.

Márta Péntek

marta.pentek@uni-corvinus.hu

1 Department of Health Economics, Corvinus University of Budapest, Fővám tér 8., Budapest 1093, Hungary

2 Department of Comparative Economics, Institute of Business Economics, Eötvös Loránd University, Szép u. 2, Budapest 1053, Hungary

\section{Introduction}

Assessing individuals' subjective expectations has come into focus in the past years in healthcare. Patientreported outcomes (PRO) play an increasing role in drug

3 Premium Postdoctoral Research Programme, Hungarian Academy of Sciences, Nádor u. 7, Budapest 1051, Hungary

4 Doctoral School of Business and Management, Corvinus University of Budapest, Fővám tér 8., Budapest 1093, Hungary

5 Department of Macroeconomics, Corvinus University of Budapest, Fővám tér 8., Budapest 1093, Hungary 
registration process and in medical decision making, as these are used in clinical trials and in everyday clinical practice to assess disease severity and therapeutic effectiveness [1,2]. Given that PROs reflect subjective perceptions of the patients, several personal factors might influence the valuation of these outcomes, such as preferences for some treatment forms or acceptability of certain health problems. Subjective expectations regarding health can be deterministic in the self-perceived health status assessment and unrealistic expectations about future health may lead to distortion in the evaluation of health gains [3, 4]. Inaccurate health expectations may have influence also on actual health behaviour in terms of, for instance, participation in preventive care, living a healthy lifestyle or choosing an insurance plan.

Brouwer and colleagues highlighted that overestimation may be present in life expectancy and age, current health, and perception of healthy lifestyle are important explanatory factors of people's subjective expectations regarding future health-related quality of life [3, 4]. Similar findings were reported from Hungary in a study involving a convenient online sample of the general population [5]. Underestimation of future health status from age 70 and onwards (i.e., expecting worse states than the general population has in these ages) was typical in both countries. Subsequent studies involving patients with chronic diseases (rheumatoid arthritis, psoriasis, and age-related macular degeneration) in Hungary revealed that patients' do expect a significant deterioration of health with age but may overestimate treatment effects on the short term [5-7]. However, up to date, little is known about how individuals think about the consequences of age-related worsening of health, namely, how they plan to cope with health problems and how it will affect their happiness and mental well-being. Subjective expectations regarding retirement, needs, and demands for care services and financial consequences are poorly studied, although these are highly relevant for workforce, healthcare, and social care planning in ageing societies $[8,9]$.

From the methodological point of view, several questionnaires have been developed in the past years to measure patients' expectations regarding healthcare services, treatment choices, or outcomes [10-16]. However, these are mainly disease-specific or focus on specific needs and hence cannot be used in studies of the general population. Brouwer and colleagues were the first to use the EQ-5D instrument, a preference-based health status measure, to assess subjective health expectations (SHE) for future ages [3, 17]. Applying the EQ-5D to explore SHE has important advantages. First, population norm data are available in many countries with this general health status measurement tool [18]. Comparing EQ-5D-based SHE to the EQ-5D health status of the agematched general population allows to identify tendencies of over- and underestimation of future health. Second, EQ-5D has been used in routine outcomes measurement in healthcare systems over the past years [19]. Getting an insight into individuals' and patients' SHE with the EQ-5D can help a better understanding and interpretation of healthcare performance results. Third, EQ-5D is the most often used tool to calculate quality-adjusted life years (QALY) in economic evaluations [20]. EQ-5D-based SHE assessments can provide, therefore, comparable data on individuals' subjective QALY expectations [4]. In the previous SHE studies, the three-level version of the EQ-5D questionnaire (EQ-5D-3L) was used to assess health provisions for future ages [3-7]. A new version with five response levels (EQ-5D-5L) was developed in 2009 to improve sensitivity and reduce ceiling effects, as compared to the EQ-5D-3L [21]. Population norm and valuation studies with the $5 \mathrm{~L}$ have been performed and are ongoing in various countries and an increasing spread of its use can be observed $[18,22]$. Therefore, we believe that there will be an increasing need for SHE data with the EQ$5 \mathrm{D}-5 \mathrm{~L}$ and also to find ways to convert $3 \mathrm{~L}$ - and $5 \mathrm{~L}$-based SHE results to each other.

While EQ-5D is widely used in health economic evaluations, large international social surveys such as the European Statistics of Income and Living Condition (EU-SILC) or the European Health Interview Survey (EHIS) apply the Minimum European Health Module including the Global Activity Limitations Indicator (GALI) [23]. GALI is the measure underlying the European indicator Healthy Life Years (HLY) hence using GALI to assess SHE can provide valuable information about potential discrepancies between statistically and subjectively expected HLYs [24].

The primary aim of our study was, therefore, to investigate subjective expectations regarding health and happiness at future ages and analyze the determining factors. To provide comparable data with clinical studies and routinely collected health statistics, we used four standardized health status measures (EQ-5D-3L, EQ-5D-5L, GALI, and WHO5) to explore SHE. Secondarily, we aimed to investigate the expected drug costs, care needs and forms of care for older ages, as well as the expected retirement age and financial circumstances for the elderly.

\section{Methods}

\section{Sample and study design}

A cross-sectional online survey was performed among the adult Hungarian general population in early 2019. Authorization by the national ethical committee was obtained (5113-2/2018/EKU). Respondents gave their written consent to participate in the study. Data collection was preceded by a pilot survey $(N=204)$ before the questionnaire was finalized. Programing the questionnaire to online and 
recruitment of the respondents was conducted by a survey company (Big Data Scientist Kft.). We aimed to achieve a sample $(N=1000)$ representative for the Hungarian adult population in terms of gender, age (by age groups of 18-24, 25-34, 35-44, 45-54, 55-64, and a reasonable sample for age 65 and over), educational level (primary, secondary, and tertiary) and type of settlement (capital, town, and village), and region (Central, Eastern, and Western) of the country using quotas.

\section{Measurement tools}

\section{EQ-5D-5L and EQ-5D-3L}

The EQ-5D-5L questionnaire is a health status measure that consists of two parts, a descriptive system and an EQ VAS. The descriptive system focuses on five dimensions of current health: mobility, self-care, usual activities, pain/ discomfort, and anxiety/depression with five response categories for each (no problems-1, slight problem-2, moderate problems - 3 , severe problem -4 , and extreme problems-5) [21]. To each health state description, a utility score (EQ-5D-5L index) can be attached reflecting the general population's preference for the given health state. In the absence of a Hungarian value set, we used the tariffs of England [25, 26]. The second part of the questionnaire is a visual analogue scale (EQ VAS) ranging from 0 to 100 representing the worst and best imaginable health state the respondent can imagine.

The EQ-5D-3L is the original instrument with three response levels (1-no problems; 2 -some/moderate problems; and 3-unable/extreme problem) in the descriptive system [17]. We used the UK value set to calculate EQ5D-3L index scores [27].

\section{Minimum European Health Module (MEHM)}

The MEHM consists of three general questions characterizing three different concepts of health: self-perceived health, chronic morbidity, and activity limitation. Self-perceived health covers the self-assessment of a person's own health in general, with answer categories: "Very good/Good/Fair/ $\mathrm{Bad} /$ Very bad", while chronic morbidity focuses on the presence of any long-standing (for at least the past 6 months) health problem (yes/no). Global Activity Limitation Indicator (GALI) refers to the presence of long-standing (for at least the past 6 months) participation limitation due to health problems (severely limited/limited but not severely or/not limited at all) in activities that people usually do.

\section{Happiness}

Happiness was measured on 11-step numeral happiness scale (hereinafter happiness VAS) in which the extremes were denoted as "completely unhappy" (0) and "completely happy" (10). Respondents were asked to indicate their current happiness by marking a point between 0 and 10 on the scale. This tool is also part of the CarerQol questionnaire assessing the quality of life of informal caregivers [28].

\section{World Health Organisation-Five Well-Being Index (WHO-5)}

The WHO-5 is a self-reported measure of mental well-being. This questionnaire consists of five items (feel cheerful and in good spirits; calm and relaxed; active and vigorous; wake up fresh and rested; and daily life filled with thing that interests me) and a six-point Likert scale for each (all of the time- 5 , most of the time- 4 , more than half of the time- 3 , less than half of the time -2 , some of the time- -1 , and at no time- 0 ) with respect to the past 2 weeks. The score is calculated by totaling the figures of the five answers (range 0-25). In our study, we used a modified version of the questionnaire with a simplified five-point Likert-scale ('some of the time' was left out) to make the expectations questions more simple. Similar modification of the questionnaire has already been used in population surveys [29, 30]. For the analysis, responses were grouped into two subgroups (all/most of the time; other) and no score was calculated.

\section{Assessment of respondents' current status}

Basic demographic data of the respondents were recorded. Age of the respondents' youngest and oldest child (if any) were registered. The number of persons living in the household, as well as the monthly net income and spending on drugs was surveyed.

We used the validated Hungarian version of the EQ5D-5L questionnaire and the MEHM to assess the respondents' health status, as well as the happiness VAS and the simplified WHO-5. Body mass index (BMI) and self-perceived healthy lifestyle were recorded. Smoking habits, sport activities, and alcohol consumption were assessed using the same questions as the European Health Interview Survey (EHIS) [31].

Current drug expenditures were assessed on the household level. Informal care received (help from family members to perform everyday activities that are limited due to health problems or ageing) was surveyed and respondents were asked whether they themselves were informal caregivers. 


\section{Assessment of expectations regarding future health and happiness}

In the second part of the questionnaire, participants were asked to indicate the health status they expect for future ages. The questions were focused on ages $60,70,80$, and 90 , and only those respondents were required to answer who were younger than the age the question was referring to. Questions were formulated based on the descriptive part of the EQ-5D-5L and the EQ-5D-3L, GALI, happiness VAS, and simplified WHO-5 (Supplementary Table S1).

\section{Assessment of subjective perspectives on drug costs, care needs, and access to care}

We asked the participants to indicate the expected spending on pharmaceutical products in their household at ages 60 , 70,80 , and 90 , in the percentage of household's monthly net income. Estimates on future care needs (h/week) and type of care they will use were surveyed (staying in their own home and being helped by volunteer family members/non-professionals paid by the respondent; moving to the home of close relatives to be helped; moving to institutions provided by the healthcare/social system with no co-payment; moving to institutions by own choice with significant costs; and other).

\section{Assessment of expected retirement age and financial circumstances for the elderly}

To access the expected labor and financial situation in the future, subjective life expectancy was asked and the age respondents expect to do paid work. We surveyed also whether they think to have any regular income other than their pension after having stopped working (income from property or assets; private insurance or financial aid from family member; other).

\section{Statistical analysis}

Survey data were recorded in a database created in IBM SPSS Statistics 25 (IBM SPSS, Version 25.0. Armonk, NY, USA: IBM Corp., 2012). Descriptive statistics were conducted and explanatory factors associated with subjective health and happiness expectations were investigated. To analyze the determinants of subjective expectations on future health (measured with the EQ-5D-5L index) and future happiness (happiness VAS), we built separate regression models. The explanatory variables in our models were: sociodemographic characteristics (gender, marital status, level of education, employment, and household net income); measures of current health and happiness (EQ-5D-5L index, EQ
VAS, self-perceived health scale, GALI, chronic morbidity, and happiness VAS); determinants of health (self-perceived healthy lifestyle, BMI, alcohol and tobacco consumption, and sport activities); informal care experience (informal care received or provided); and longevity factors (close relatives' age at death and subjective life expectancy). Categorical (nominal) variables (gender, employment, and marital status) were included in the model using dummy variables. Modelling the marginal effects of explanatory variables on the EQ-5D-5L dependent variable was estimated by linear regression coefficients yielding also the standardized version of the coefficients, significance $p$ values, and goodness-of-fit $R^{2}$ indices. The regression models for current and expected happiness were built similarly. While modelling statistical correlations and regression relationships, the computations were carried out by the means of stepwise ordinary least squares (OLS) method. As a result of OLS, we get the rank, significance and explanatory power of independent variables that have entered the current model. The subset of the relevant predictors has been selected based on the adjusted $R^{2}$ goodness-of-fit measure. In addition, the so-called standardized regression coefficients represent the relative importance of the explanatory variables. The applied currency exchange rate was: $€ 1=314$ HUF.

\section{Results}

\section{Sample}

Our sample consisted of 1000 respondents (Table 1). Descriptive statistics show (using a conventional 5\% significant level of decision) that the sample represents the whole population considering basic demographic distributions.

The rate of females was $54.5 \%$ and average age was 50.9 (15.4) years (range 18-85). Based on respondents' age, questions about subjective expectations for future ages of $\geq 60, \geq 70, \geq 80$, and 90 were relevant for $623,898,990$, and 1000 respondents, respectively. Main socio-demographic characteristics of the participants are presented in Table 1. The average household size was $2.5(\mathrm{SD}=1.7)$, $23.8 \%$ were one-person households, and in $76.3 \%$ of the cases, no child (aged $<18)$ lived in the household. These results are in line with Hungarian micro-census data from 2016 [32]. The majority (69.8\%) had children (of any age); among them, $34.1 \%$ had only one child (with mean age of $24.5, \mathrm{SD}=15.8$ years). Age of the youngest and oldest child among respondents having more than one child was 26.6 ( $\mathrm{SD}=14.0$, range $0-61)$ and $32.7(\mathrm{SD}=13.4$, range: $0-65)$, respectively. 
Table 1 Sociodemographic characteristics of the sample and general population reference values

\begin{tabular}{|c|c|c|c|}
\hline Variable & Category & $\begin{array}{l}\text { Sample, } \% \\
(N=1000)\end{array}$ & $\begin{array}{l}\text { Sample }(N=1000) \text { weighted for gender, age, edu- } \\
\text { cational level, region and type of settlement }{ }^{\mathrm{a}}(\%)\end{array}$ \\
\hline \multirow[t]{2}{*}{ Gender } & Female & 54.5 & 53.4 \\
\hline & Male & 45.5 & 46.6 \\
\hline \multirow[t]{6}{*}{ Age (years) } & $18-24$ & 5.2 & 10.6 \\
\hline & $25-34$ & 11.5 & 16.9 \\
\hline & $35-44$ & 22.1 & 18.8 \\
\hline & $45-54$ & 18.0 & 15.5 \\
\hline & $55-64$ & 19.2 & 17.6 \\
\hline & $65+$ & 24.0 & 20.6 \\
\hline \multirow[t]{3}{*}{ Educational level } & Primary & 30.0 & 51.0 \\
\hline & Secondary & 42.2 & 31.3 \\
\hline & High school/university & 27.8 & 17.7 \\
\hline \multirow[t]{3}{*}{ Region } & Central & 33.8 & 30.0 \\
\hline & Eastern & 38.2 & 39.6 \\
\hline & Western & 28.0 & 30.4 \\
\hline \multirow[t]{3}{*}{ Type of settlement } & Capital (Budapest) & 22.3 & 18.1 \\
\hline & Town & 52.3 & 51.9 \\
\hline & Village & 25.4 & 30.0 \\
\hline \multirow[t]{6}{*}{ Marital status } & Married & 42.5 & 38.9 \\
\hline & Living together & 17.1 & 20.1 \\
\hline & Single & 20.1 & 22.5 \\
\hline & Divorced & 11.6 & 10.1 \\
\hline & Widow & 7.5 & 6.7 \\
\hline & Other & 1.2 & 1.6 \\
\hline \multirow[t]{9}{*}{ Employment status } & Full time & 47.0 & 43.9 \\
\hline & Part-time & 4.6 & 6.0 \\
\hline & Retired & 29.5 & 25.7 \\
\hline & Disability pensioner & 4.2 & 5.0 \\
\hline & Student & 1.6 & 2.9 \\
\hline & Unemployed (seeking job) & 4.7 & 5.8 \\
\hline & Unemployed (not seeking job) & 1.0 & 0.9 \\
\hline & Housewife/husband & 3.2 & 4.6 \\
\hline & Other & 4.2 & 5.2 \\
\hline \multirow{12}{*}{$\begin{array}{l}\text { Household net income, } \\
\text { Euro/month }^{\mathrm{b}}\end{array}$} & $0-159$ & 2.6 & 3.1 \\
\hline & $160-318$ & 4.5 & 6.1 \\
\hline & $319-478$ & 9.9 & 11.3 \\
\hline & $479-637$ & 12.7 & 12.6 \\
\hline & $638-796$ & 12.3 & 12.7 \\
\hline & $797-955$ & 13.1 & 12.8 \\
\hline & $956-1115$ & 8.3 & 8.0 \\
\hline & $1116-1274$ & 5.5 & 5.3 \\
\hline & $1275-1433$ & 3.4 & 2.6 \\
\hline & $1434-1592$ & 4.6 & 3.7 \\
\hline & $1593-$ & 5.8 & 4.9 \\
\hline & Missing data & 17.3 & 17.0 \\
\hline
\end{tabular}

${ }^{a}$ Based on general population over 18 years of age, 2011 European Census Data. For all analyses, we used the data of the non-weighted sample ${ }^{\mathrm{b}}$ Conversion: $1 \mathrm{EUR}=314 \mathrm{HUF}$ 


\section{Current health, happiness, drug expenditures, and informal care}

Current status of the sample is presented in Tables 2 and 3. EQ VAS result of the sample was similar to that of the general population (mean 76.2 vs. 71.1 ) $[18,33]$ (EQ-5D-5L index population norm is not yet available in Hungary.). Altogether, $57.5 \%$ of the sample perceived to be in very good or good health status which is very close to the $60 \%$ in Eurostat statistics (aged 16 and over), but more respondents reported to have a chronic morbidity $(52.5 \%$ vs. $38.2 \%)[34$, 35].

The happiness score of the sample was in average 6.7 ( $\mathrm{SD}=2.4$; range 0-10). For comparison, in the European Quality of Life Survey (EQLS), the average happiness of the Hungarian adult population was 7.0 on a scale between 1 and 10 [36].

The average monthly spending on drugs in the household was $€ 29.3 /$ month $(\mathrm{SD}=43.5)$ and an increase was observed across age groups (55-64, 65-74, and 75-84: mean €28.7, $€ 38.1$, and $€ 47.6$, respectively). In Hungary, the yearly drug expenses per capita in average were $€ 86$ in 2010 and $€ 115$ in 2017, and this latter corresponds to about $€ 22 /$ month per household in 2017 (2.9\% of the average household income) $[37,38]$.

Altogether, 76 respondents reported to receive informal care and 11 paid care. Further 30 individuals did not receive care, but would have needed according to their self-report. Altogether, $11 \%$ of the sample was caregiver (for at least 6 weeks) at the time of the survey and the average care time was 54.4 (15.7) h per week. Further $27.9 \%$ provided informal care in the past 10 years (but not now). In age-group 50 and over $(N=542)$, the number of current informal caregivers was $73(13.5 \%)$ that is close to the OECD average (13.3\%) [39].

\section{Expected health and happiness}

Participants' subjective expectations for future ages are presented in Table 3. There was only one respondent in age group 85+; hence, we got no accountable data to make
Table 2 Health status and some determinants of health $(N=1000)$

\begin{tabular}{|c|c|c|}
\hline Variable & Category & $N(\%)$ \\
\hline \multirow[t]{5}{*}{ Self-perceived health ${ }^{\mathrm{a}}$} & Very good & $114(11.4 \%)$ \\
\hline & Good & $461(46.1 \%)$ \\
\hline & Fair & $327(32.7 \%)$ \\
\hline & $\mathrm{Bad}$ & $87(8.7 \%)$ \\
\hline & Very bad & $11(1.1 \%)$ \\
\hline \multirow[t]{4}{*}{ Chronic morbidity } & Yes & $525(52.5 \%)$ \\
\hline & No & $380(38.0 \%)$ \\
\hline & I do not know & $86(8.6 \%)$ \\
\hline & I do not want to answer & $9(9 \%)$ \\
\hline \multirow[t]{4}{*}{ Body mass index (BMI) kg/m² } & Underweight $(<18.5)$ & $36(3.6 \%)$ \\
\hline & Normal $(\geq 18.5$ and $<25)$ & $309(30.9 \%)$ \\
\hline & Overweight $(\geq 25$ and $<30)$ & $345(34.5 \%)$ \\
\hline & Obese $(\geq 30)$ & $310(31.0 \%)$ \\
\hline \multirow[t]{3}{*}{ Healthy lifestyle } & Healthier than most others & $210(21.0 \%)$ \\
\hline & Comparable to others & $614(61.4 \%)$ \\
\hline & Less healthy than most others & $176(17.6 \%)$ \\
\hline \multirow[t]{4}{*}{ Smoking status } & Current smoker & $299(29.9 \%)$ \\
\hline & Quitted smoking within a year & $25(2.5 \%)$ \\
\hline & Quitted smoking more than a year ago & $252(25.2 \%)$ \\
\hline & Never smoked & $424(42.4 \%)$ \\
\hline \multirow[t]{6}{*}{ Alcohol consumption } & Every day or nearly every day & $67(6.7 \%)$ \\
\hline & $1-6$ days per week & $205(20.5 \%)$ \\
\hline & $1-3$ times per month & $217(21.7 \%)$ \\
\hline & Less than once per month & $248(24.8 \%)$ \\
\hline & Not in the past 12 months & $76(7.6 \%)$ \\
\hline & Never or only a few times in life & $187(18.7 \%)$ \\
\hline \multirow{2}{*}{$\begin{array}{l}\text { Sports (min. } 10 \text { min' sport at least one } \\
\text { day per week) }\end{array}$} & Yes & $515(51.5 \%)$ \\
\hline & No & $485(48.5 \%)$ \\
\hline
\end{tabular}


Table 3 Current and expected status for future ages

\begin{tabular}{|c|c|c|c|c|c|}
\hline \multirow[t]{2}{*}{ Variable } & \multirow[t]{2}{*}{ Current } & \multicolumn{4}{|c|}{ Subjective expectations for age ... } \\
\hline & & 60 & 70 & 80 & 90 \\
\hline$N$ & 1000 & 623 & 898 & 990 & 1000 \\
\hline EQ-5D-5L index ( -0.285 to 1.000$)$, Mean (SD) & $0.869(0.164)$ & $0.761(0.263)$ & $0.684(0.306)$ & $0.554(0.370)$ & $0.402(0.423)$ \\
\hline EQ-5D-3L index (-0.594 to 1.000$)$, Mean (SD) & NA & $0.712(0.356)$ & $0.569(0.429)$ & $0.333(0.522)$ & $0.113(0.571)$ \\
\hline Happiness (0-10), Mean (SD) & $6.7(2.4)$ & $6.8(2.5)$ & $6.7(2.5)$ & $6.2(2.7)$ & $5.7(3.1)$ \\
\hline \multicolumn{6}{|l|}{ Activity limitation (GALI) $)^{\mathrm{a}}, N(\%)$} \\
\hline Not limited at all & $619(61.9 \%)$ & $396(63.5 \%)$ & $358(39.9 \%)$ & $182(18.4 \%)$ & $136(13.6 \%)$ \\
\hline Limited but not severely & $310(31.0 \%)$ & $202(32.4 \%)$ & $453(50.4 \%)$ & $556(56.2 \%)$ & $411(41.1 \%)$ \\
\hline Severely limited & $46(4.6 \%)$ & $25(4.0 \%)$ & $87(9.7 \%)$ & $252(25.5 \%)$ & $453(45.3 \%)$ \\
\hline \multicolumn{6}{|l|}{ WHO-5, $N(\%)$} \\
\hline Feel cheerful and in good spirits-all or most of the time & $522(52.2 \%)$ & $364(58.4 \%)$ & $460(51.2 \%)$ & $399(40.3 \%)$ & $326(32.6 \%)$ \\
\hline Less or never & $478(47.8 \%)$ & $259(41.6 \%)$ & $438(48.8 \%)$ & $591(59.7 \%)$ & $674(67.4 \%)$ \\
\hline Feel calm and relaxed-all or most of the time & $439(43.9 \%)$ & $312(50.1 \%)$ & $436(48.6 \%)$ & $386(39.0 \%)$ & $319(31.9 \%)$ \\
\hline Less or never & $561(56.1 \%)$ & $311(49.9 \%)$ & $462(51.4 \%)$ & $604(61.0 \%)$ & $681(68.1 \%)$ \\
\hline Feel active and vigorous & $457(45.7 \%)$ & $272(43.7 \%)$ & $342(38.1 \%)$ & $289(29.2 \%)$ & $224(22.4 \%)$ \\
\hline Less or never & $543(54.3 \%)$ & $351(56.3 \%)$ & $556(61.9 \%)$ & $701(70.8 \%)$ & $776(77.6 \%)$ \\
\hline Wake up fresh and rested & $356(35.6 \%)$ & $242(38.8 \%)$ & $339(37.8 \%)$ & $291(29.4 \%)$ & $245(24.5 \%)$ \\
\hline Less or never & $644(64.4 \%)$ & $381(61.2 \%)$ & $559(62.2 \%)$ & $699(70.6 \%)$ & $755(75.5 \%)$ \\
\hline Daily life filled with thing that interests me & $366(36.6 \%)$ & $252(40.4 \%)$ & $334(37.2 \%)$ & $292(29.5 \%)$ & $245(24.5 \%)$ \\
\hline Less or never & $634(63.4 \%)$ & $371(59.6 \%)$ & $564(62.8 \%)$ & $698(70.5 \%)$ & $755(75.5 \%)$ \\
\hline \multicolumn{6}{|l|}{ Care need $^{\mathrm{b}}(\mathrm{h} /$ week $), N(\%)$} \\
\hline 0 & $917(91.7 \%)$ & $436(70.0 \%)$ & $409(45.5 \%)$ & $192(19.4 \%)$ & $126(12.6 \%)$ \\
\hline $1-4$ & $23(2.3 \%)$ & $112(18.0 \%)$ & $270(30.1 \%)$ & $303(30.6 \%)$ & $200(20.0 \%)$ \\
\hline $5-7$ & $10(1.0 \%)$ & $38(6.1 \%)$ & $123(13.7 \%)$ & $242(24.4 \%)$ & $175(17.5 \%)$ \\
\hline $8-28$ & $36(3.6 \%)$ & $21(3.4 \%)$ & $55(6.1 \%)$ & $142(14.3 \%)$ & $213(21.3 \%)$ \\
\hline $29-56$ & $10(1.0 \%)$ & $10(1.6 \%)$ & $25(2.8 \%)$ & $65(6.6 \%)$ & $146(14.6 \%)$ \\
\hline More than 56 & $4(0.4 \%)$ & $6(1.0 \%)$ & $16(1.8 \%)$ & $46(4.6 \%)$ & $140(14.0 \%)$ \\
\hline \multicolumn{6}{|l|}{ Expects to be in a paid job (part time or full time) ${ }^{\mathrm{c}}$} \\
\hline Yes & NA & $540(92.8 \%)$ & $239(35.5 \%)$ & $45(6.5 \%)$ & $20(2.9 \%)$ \\
\hline No & NA & $42(7.2 \%)$ & $433(64.4 \%)$ & $643(93.5 \%)$ & $668(97.1 \%)$ \\
\hline
\end{tabular}

NA not available/not applicable

${ }^{a}$ Current status on GALI, further responses: 'I do not know' $N=19$ (1.9\%); 'I do not want to answer' $N=6(0.6 \%)$

${ }^{b}$ For the current status, we present the hours of care received (professional and informal care together)

${ }^{\mathrm{c}}$ Those respondents who have already definitely stopped working were not included in this analysis

comparisons between the expectations for age 90 and the sample's age-matched actual score.

The expected mean EQ-5D-5L scores for ages 60, 70, and 80 were lower than of the actual EQ-5D-5L score of the age-matched sample (in age groups 55-64, 65-74, and $75-84: 0.761$ vs. $0.853 ; 0.684$ vs. 0.840 ; and 0.554 vs. 0.820 , respectively). Respondents expected a sharp deterioration of health with age as measured by the EQ$5 \mathrm{D}-3 \mathrm{~L}$ and the difference is remarkable compared to the Hungarian general population's health status from age 70 and over (Fig. 1).

Participants expected in average a decline of happiness with age (Table 3). According to EQLS data, in Hungary, happiness (on a 1-10 scale) was the highest in age group 25-34 (7.7) with a decreasing tendency with age, being the lowest (6.3) in age group 65+, that is close to the expected scores of the sample [36].

Correlations between expected EQ-5D-3L, EQ-5D-5L, and happiness VAS were positive and significant for all the four future ages. It was high (Spearman rank correlation coefficients > 0.7) between the two versions of the EQ-5D and low bordering to moderate (Spearman rank correlation coefficients around 0.4 and 0.5 ) between the expected EQ-5D measures and expected happiness VAS (data not shown.) 


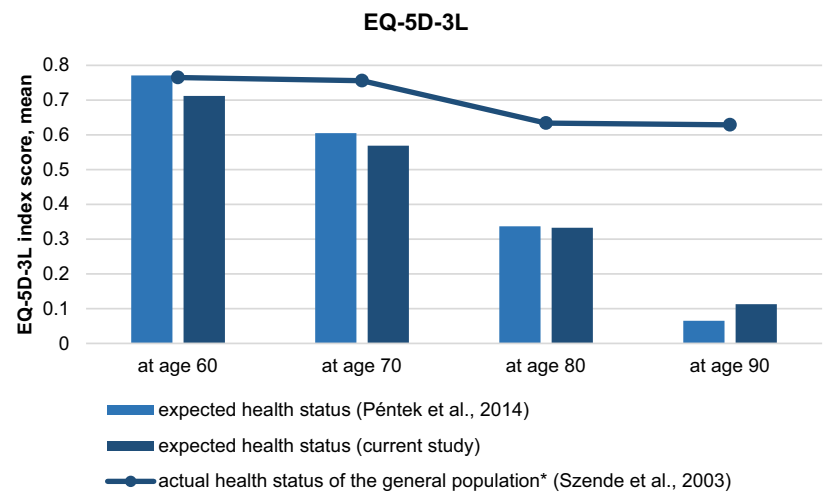

Fig. 1 Expected health status for future ages (current and a previous study) in comparison with the health status of the general population. *in age groups $55-64,65-74,75-84$, and $85+$

\section{Determinants of subjective expectations on future health (EQ-5D-5L) and happiness}

In the models for SHE (EQ-5D-5L index) for future ages, current EQ-5D-5L index was significant for expected status at ages 60 and 70 (Table 4). For ages 70, 80, and 90, current activity limitation (GALI) and educational level were significant predictors. BMI was negatively associated with SHE for ages 70 and 80 , while subjective life expectancy was positively associated for ages 80 and 90 .

Current happiness was significant explanatory variable for expected happiness for all the four future ages (Supplementary Table S2). Current self-perceived health and informal care received (h/week) were significant predictors of future happiness at ages 70, 80, and 90. Gender was significant in the model for expected happiness at ages 70 and 80 . The presence of chronic morbidity was negatively associated with expected happiness for ages 70 and 80 . Current informal care received (h/week) was positively associated with happiness expectations for ages 70,80 , and 90 . Actual monthly income was not significant in any of the models. Only few of the variables expressing marital and employment status were significant in the models.

\section{Provisions on drug costs, care needs, and forms of care for future ages}

Drug expenses and types of care expected for ages 60, 70, 80, and 90 are resented by Fig. 2. A shift in direction of a higher share of drug expenses of the household net income was forecasted by the participants (Fig. 2a), and an increasing need for care (h/week) was provisioned (Table 3). Expectations on being helped in their own home by family members (informal care) were dominant for all future ages, although with a decreasing tendency (Fig. 2b). Characteristics of the sample expecting different forms of care at age 80 are presented in supplementary file (Supplementary Table S3).

\section{Expected working status and incomes for future ages}

A substantial number of respondents $(N=40)$ indicated ages between 101 and 120 for subjective life expectancy. Applying a maximum limit of 100 years, respondents $(N=941)$ expected to live up to age $80.9(\mathrm{SD}=11.1)$, females 81.1 ( $\mathrm{SD}=11.5)$, males $80.7(\mathrm{SD}=10.8)$. For comparison, life expectancy at birth was 79.0 years for females and 72.4 for males in 2017 in Hungary and life expectancy at age 65 was 14.6 and 18.7 years, respectively.

Share of respondents who expected to work in a paid job at ages $60,70,80$, and 90 is presented in Table 3 (those who have definitely stopped working in a paid job were excluded from the analysis). Median expected age of stopping doing paid work was 65 years, and it was mean 63.5 $(\mathrm{SD}=7.5), 66.1(\mathrm{SD}=7.3), 67.2(\mathrm{SD}=8.1), 67.2(\mathrm{SD}=7.5)$, $66.8(\mathrm{SD}=5.6)$, and $75.7(\mathrm{SD}=7.0)$ in age groups $18-24$, 25-34, 35-44, 45-54, 55-64, and 65+, respectively. Women expected somewhat lower age than men (mean 66.0 vs. 68.5), and altogether, $48.4 \%$ expected not to have any extra income besides pension, respectively. Private insurance $(22.2 \%)$, renting out the house (14.8\%), financial help from family members $(10.3 \%)$, and stocks $(6.3 \%)$ were marked and a large variety of other possibilities were mentioned (e.g., selling the flat, from savings, etc.) but all at low proportions.

\section{Discussion}

In this study, we assessed subjective expectations regarding future health and happiness of the Hungarian population in an online, cross-sectional population-based survey and analyzed their determinants. According to our best knowledge, this is the first study to investigate subjective happiness expectations alongside SHE for the elderly. Further novelty of this research is that we used different measurement tools in parallel to assess SHE. We applied both versions (3L and 5L) of the EQ-5D questionnaire to explore SHE, allowing comparisons with $3 \mathrm{~L}$ - and $5 \mathrm{~L}$-based studies. We used the GALI instrument to provide comparable data for healthy life year (HLY) calculations and the WHO-5 questionnaire to obtain information about mental well-being expectations. Moreover, subjective expectations on drug expenses, care needs, and forms of care for the elderly were surveyed, and provisions on working and financial status for older ages were investigated aiming to provide a broader picture about the population's ideas regarding ageing. 


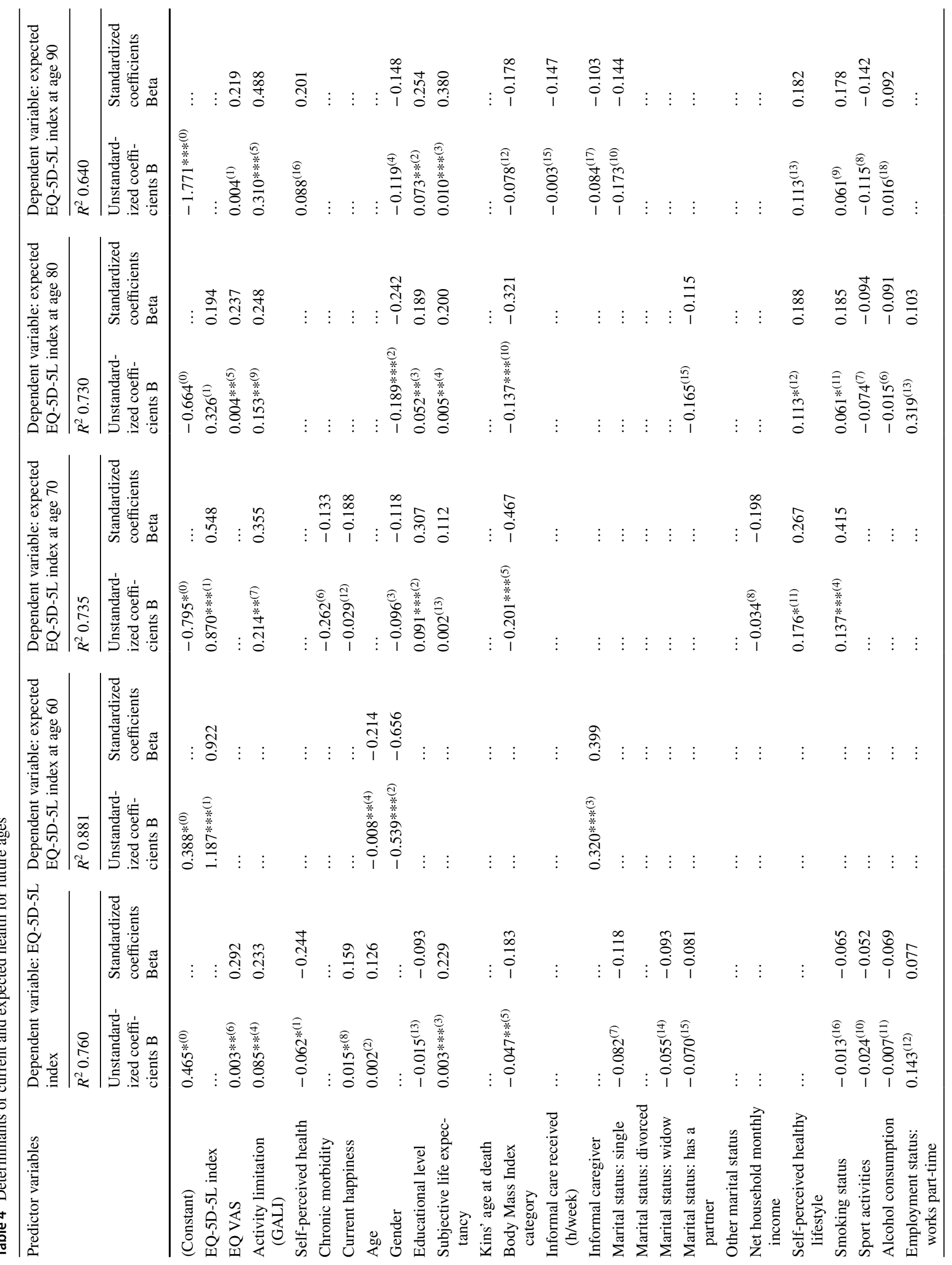




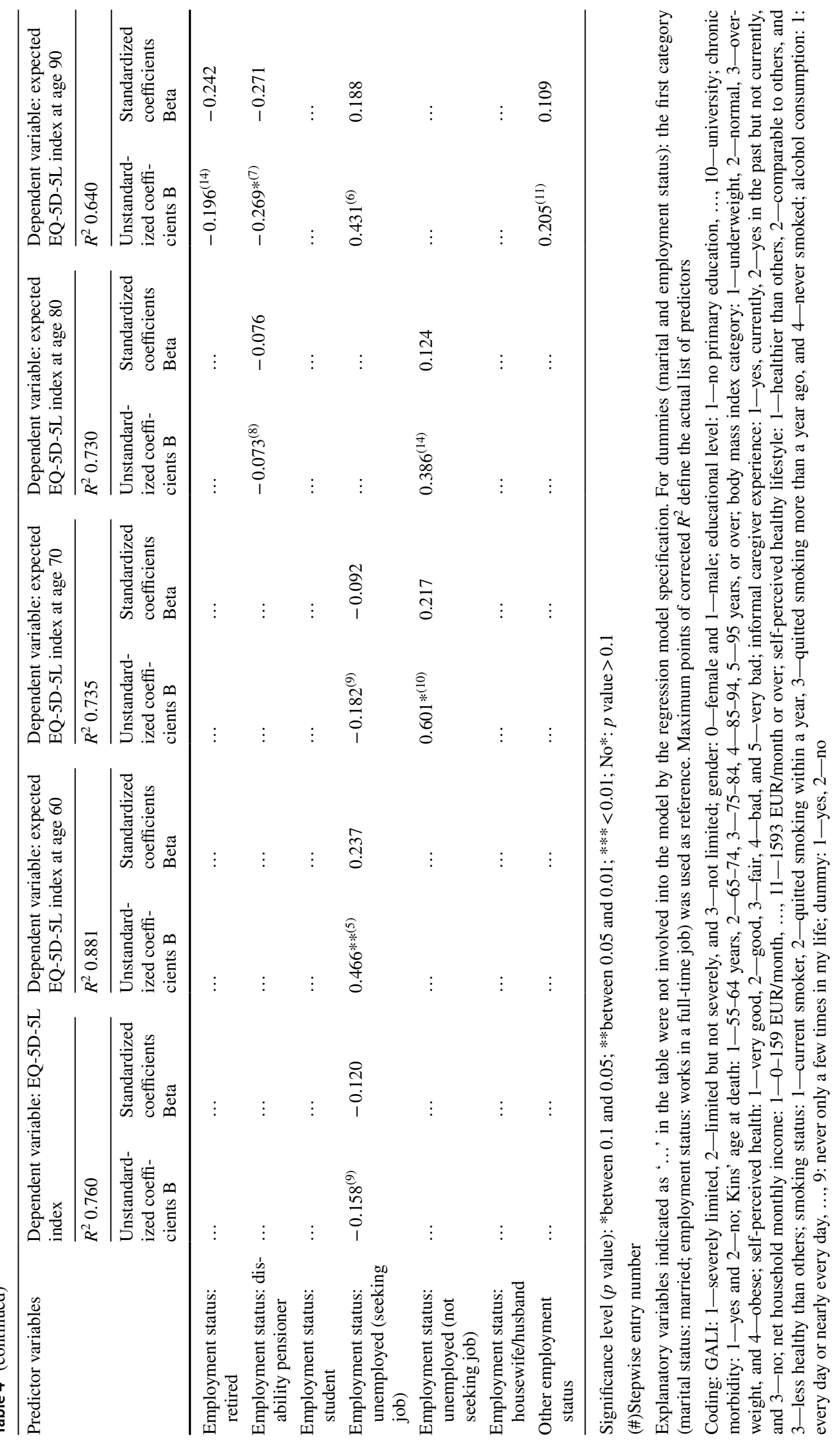




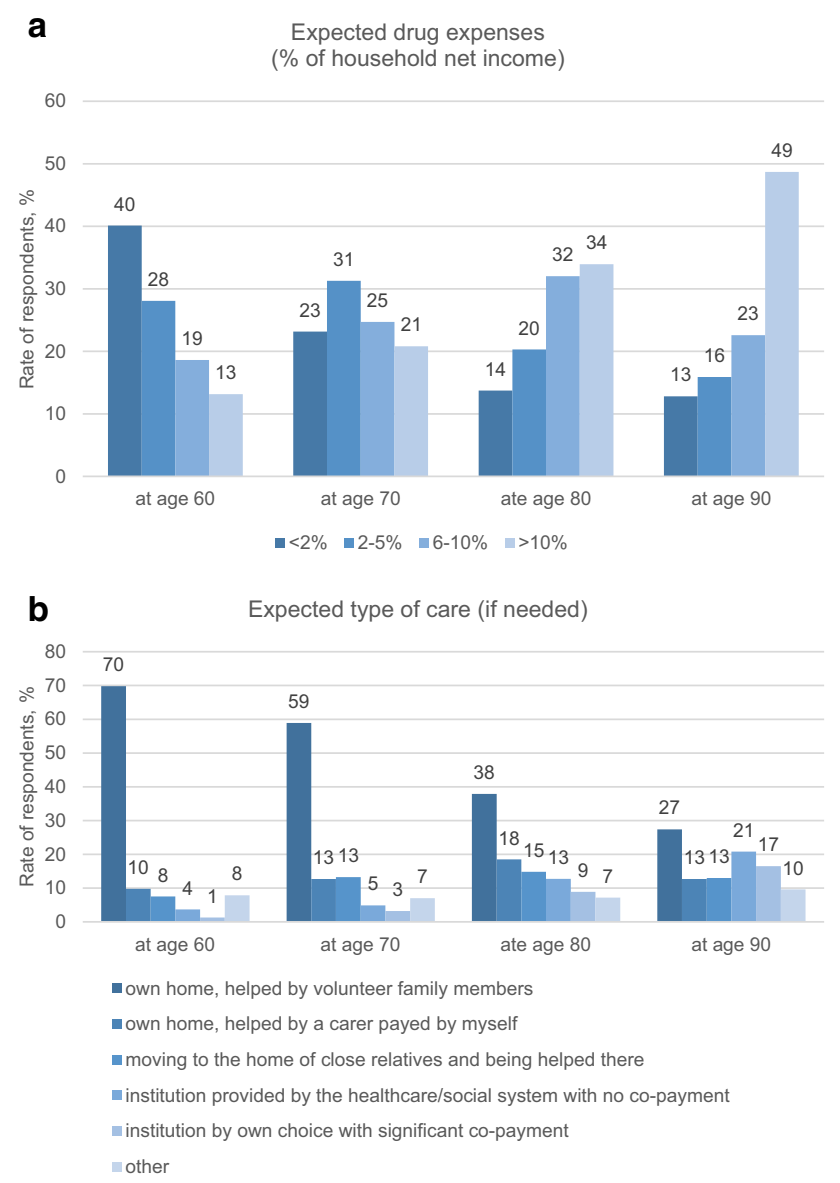

Fig. 2 Expected drug expenses and forms of care for future ages

Our results on SHE as measured by the EQ-5D-3L confirm the findings of the previous studies in The Netherlands and of a non-representative population survey in Hungary [3-5]. Individuals expect a deterioration of health with age and an underestimation of health can be observed for age 70 and over compared to the age-matched actual health status of the population (Fig. 1). Adaptation to deteriorating health with age might be one explanation of this difference [40]. We found strong correlations between the EQ-5D-3L and EQ-5D-5L-based SHE results indicating that good estimates can be calculated from one to another in case of lack of available data.

The expected deterioration of health with age measured by the EQ-5D questionnaires was confirmed by the GALI instrument as well (Table 3). More than $80 \%$ of the respondents expected to have moderate or severe activity limitation at age 80 and $45 \%$ believed to be severely limited at age 90. Moreover, similar to the EQ-5D-based findings (Fig. 1), underestimation of future health for age 70 and over was apparent also with the GALI. According to Eurostat data, some or severe activity limitation (GALI) was present in 34 , 47,65 , and $82 \%$ in age groups of $55-64,65-74,75-84$, and
$85+$ of the Hungarian population, while the sample's future estimates for ages $60,70,80$, and 90 were $36,60,82$, and $86 \%$, respectively [41]. Although statistical and subjective life-expectancy data have to be considered in further analyses, results suggest a gap between the statistical HLY and subjectively expected HLY of the population.

According to participants' beliefs, health deterioration will be accompanied by a less sharp decrease in happiness in their life, as they indicated in average a value of 6.8 for age 60 and 5.7 for age 90 . A worsening of mental health as measured by the WHO-5 was observed in people's expectations. This can be partly explained by the relatively low current mental well-being of the population. Only 36-52\% of the participants indicated to have positive feelings all or most of the time across the five dimensions of the WHO-5. For instance, only $37 \%$ reported that daily life was filled with things that interest him/her and $44 \%$ indicated that he/she felt calm and relaxed all or most of the time. These findings are congruent with EQ-5D data of the general population in which $35 \%$ reported to have moderate or severe problem in the anxiety/depression dimension of the EQ-5D-3L [42]. Expected deterioration of mental well-being for future ages was especially remarkable in the 'feel cheerful and in good spirits' and 'feel active and vigorous' dimensions (Table 3).

While in the previous SHE studies (based on the EQ5D-3L), the most important explanatory variables of SHE were age, current EQ-5D-3L status, self-perceived healthy lifestyle, and subjective life expectancy, we found a more heterogeneous picture in our survey [3,5] (Table 4). Given that age 60 was rather close to the current age of the respondents in a substantial number of cases (Table 1), we focus on SHE for ages 70, 80, and 90. We found that current activity limitation (GALI) and educational level were significant predictors of future EQ-5D-5L expectations at all the three ages (i.e., having no activity limitation and higher educational level induced better expected health scores). Longevity expectations influenced SHE for the oldest ages (80 and 90) (Table 4). Current happiness was an important predictor of future happiness for all ages. In addition, current self-perceived health status and informal care received were also significant determinants (Supplementary Table S2).

Drug expenses are expected to increase with age and the majority of the respondents (49\%) expected to spend more than $10 \%$ of the net household income on drugs at age 90 (Fig. 2a) This partly reflects the increasing need of drugs in the elderly but probably also a relative decrease of incomes with age. It would be interesting to explore in further studies whether people expect to have limited access to drugs due to personal financial barriers.

According to our best knowledge, this is the first study to assess subjective expectations on care needs and availability of forms of care for the elderly alongside SHE. Our results confirmed that people do count with an increasing 
need for help with age. Altogether, 2.6, 4.6, 11.2, and $28.6 \%$ expected to need $29 \mathrm{~h}$ or more of care per week at age $60,70,80$, and 90, respectively (Table 3 ). Due to lack of age-specific care-time data, we cannot judge whether it is an overestimation of care needs influenced partly by the underestimation of health status from age 70 and over. A study of Rubovszky 2017 reported an average $26.7 \mathrm{~h}$ of care per week in Hungary in a sample, where $41 \%$ of the care recipients were aged 60 or older; hence, our participants' estimates seem to be rather realistic [43].

One of the most important findings of our study is that the majority of the individuals count with the support of family members if they will need long-term help in the future (Fig. 2b). Most of the respondents plan to rely on informal care $(77,72,53$, and $40 \%$ for ages $60,70,80$, and 90 , respectively) either in their own home or by moving to the family members' home to be helped there. More and more individuals expect to move to a care institution with increasing age, although its share does not exceed the informal care expectations at any age $(5,8,22$, and $37 \%$, respectively). The share of respondents considering institutions provided by the state (no co-payment) is higher for all future ages than of those who consider moving to a care institution of own choice but with significant co-payment. Given that about $48 \%$ of the samples do not expect to have extra income other than pension after retiring, the low occurrence of co-paid institutionalized care seems to be rational. It would be worthy to investigate more in depth which family members (e.g., partner or child) people expect to help them in their elderly and how much realistic these expectations are considering, for instance, their children's age and the increasing retirement age in the society. We have not explored whether the low share of care institutions in the expectations reflects availability and access barriers, or rather the preferences of the people.

The expected median age of doing paid work was 65 years. In Hungary, the standard retirement age was 63 years in 2016 and is gradually increasing to 65 in 2022. However, in our sample, even the age group 25-34 expected to retire at age 66 and similar data were found in the others as well. These findings highlight the important fact that the young generation do not count with a substantial increase of retirement age. According to an OECD report, it is suggested to adjust retirement age to increasing life expectancy in Hungary and increasing the statutory retirement age to 70 years in steps from 2029 would fully cover the projected long-term pension spending increase to $2.7 \%$ of GDP [44]. Hence, we think that there is a gap between expected and the real retirement age among the young and middle-aged population.

Some limitations of our study have to be mentioned. The part of the Hungarian population that does not use the internet and is not available in online was not represented in our sample. The measurement tools that we used to explore future expectations have been partly successfully used in the previous studies (EQ-5D-3L), but none of them were validated for such purposes. We surveyed subjective expectations for ages $60,70,80$, and 90 , as we aimed to focus on ageing. However, age 60 was probably too low for a substantial proportion of the respondents to be considered as a stage of elderly, as it is under the retirement age in Hungary. On the other hand, for the youngest respondents, age 60 was $30-40$ years far in the future; hence, it was important for us to include this age.

In conclusion, our study confirmed that individuals expect a deterioration of health with age but a much slighter decrease of happiness. Educational level and current functioning status (GALI) were significant determinants of SHE, longevity influenced SHE for the oldest ages. Happiness expectations were mainly driven by current happiness. Underestimation of health and overestimation of activity limitations was observed for age 70 and over. Significant increase in care needs with age is expected by the majority and most people think that they will be helped by informal caregivers. Moving to care institutions were forecasted only by a minority and it was more present for age 90; however, its share did not exceed the expected informal care's share even in this high age. Although retirement age will probably raise substantially in the next decades, even the youngest age groups expect to retire typically at about the current retirement age which is 65 years in Hungary. Our study contributes with valuable inputs from the societal perspective for as inputs for ageing policy, health care capacity and manpower planning, financing, and insurance scheme scenario analyses, projecting the labor force participation, as well as for health economic modelling of ageing.

Acknowledgements Open access funding provided by Corvinus University of Budapest (BCE). This research was supported by the Higher Education Institutional Excellence Program of the Ministry of Human Capacities in the framework of the 'Financial and Public Services' research project (20764-3/2018/FEKUTSTRAT) at Corvinus University of Budapest. Authors are grateful to Katalin Janák, Áron Kocsis (Hungarian Central Statistical Office) and Károly Cseh (Department of Public Health, Semmelweis University of Budapest) for their useful comments and advices.

\section{Compliance with ethical standards}

Conflict of interest In connection with writing this article, ZB and KM received grant support from the Higher Education Institutional Excellence Program of the Ministry of Human Capacities in the framework of the 'Financial and Public Services' research project (20764-3/2018/ FEKUTSTRAT) at Corvinus University of Budapest. The other authors declare that they have no conflict of interest.

Ethical standards All procedures performed in studies involving human participants were in accordance with the ethical standards of the institu- 
tional and/or national research committee and with the 1964 Helsinki declaration and its later amendments or comparable ethical standards.

Informed consent Informed consent was obtained from all participants included in the study.

Open Access This article is distributed under the terms of the Creative Commons Attribution 4.0 International License (http://creativeco mmons.org/licenses/by/4.0/), which permits unrestricted use, distribution, and reproduction in any medium, provided you give appropriate credit to the original author(s) and the source, provide a link to the Creative Commons license, and indicate if changes were made.

\section{References}

1. Fehnel, S., DeMuro, C., McLeod, L., Coon, C., Gnanasakthy, A.: US FDA patient-reported outcome guidance: great expectations and unintended consequences. Expert Rev. Pharmacoecon. Outcomes Res. 13(4), 441-446 (2013). https://doi.org/10.1586/14737 167.2013.814957

2. Porter, I., Goncalves-Bradley, D., Ricci-Cabello, I., Gibbons, C., Gangannagaripalli, J., Fitzpatrick, R., Black, N., Greenhalgh, J., Valderas, J.M.: Framework and guidance for implementing patient-reported outcomes in clinical practice: evidence, challenges and opportunities. J. Comp. Eff. Res. 5(5), 507-519 (2016). https://doi.org/10.2217/cer-2015-0014

3. Brouwer, W.B., van Exel, N.J.: Expectations regarding length and health related quality of life: some empirical findings. Soc. Sci. Med. (1982) 61(5), 1083-1094 (2005). https://doi.org/10.1016/j. socscimed.2005.01.008

4. Rappange, D.R., Brouwer, W.B., van Exel, J.: A long life in good health: subjective expectations regarding length and future healthrelated quality of life. Eur. J. Health. Econ. 17(5), 577-589 (2016). https://doi.org/10.1007/s10198-015-0701-1

5. Pentek, M., Gulacsi, L., Rojkovich, B., Brodszky, V., van Exel, J., Brouwer, W.B.: Subjective health expectations at biological therapy initiation: a survey of rheumatoid arthritis patients and rheumatologists. Eur. J. Health. Econ. 15(Suppl 1), S83-S92 (2014). https://doi.org/10.1007/s10198-014-0597-1

6. Rencz, F., Hollo, P., Karpati, S., Pentek, M., Remenyik, E., Szegedi, A., Balogh, O., Heredi, E., Herszenyi, K., Jokai, H., Brodszky, V., Gulacsi, L.: Moderate to severe psoriasis patients' subjective future expectations regarding health-related quality of life and longevity. J. Eur. Acad. Dermatol. Venereol. 29(7), 1398-1405 (2015). https://doi.org/10.1111/jdv.12884

7. Pentek, M., Brodszky, V., Biro, Z., Kolkedi, Z., Dunai, A., Nemeth, J., Baji, P., Rencz, F., Gulacsi, L., Resch, M.D.: Subjective health expectations of patients with age-related macular degeneration treated with antiVEGF drugs. BMC Geriatr. 17(1), 233 (2017). https://doi.org/10.1186/s12877-017-0619-9

8. Boncz, I., Sebestyen, A.: Financial deficits in the health services of the UK and Hungary. Lancet 368(9539), 917-918 (2006). https ://doi.org/10.1016/S0140-6736(06)69369-0

9. Kroezen, M., Van Hoegaerden, M., Batenburg, R.: The Joint Action on Health Workforce Planning and Forecasting: results of a European programme to improve health workforce policies. Health Policy 122(2), 87-93 (2018). https://doi.org/10.1016/j. healthpol.2017.12.002

10. Benhamou, M., Boutron, I., Dalichampt, M., Baron, G., Alami, S., Rannou, F., Ravaud, P., Poiraudeau, S.: Elaboration and validation of a questionnaire assessing patient expectations about management of knee osteoarthritis by their physicians: the Knee
Osteoarthritis Expectations Questionnaire. Ann. Rheum. Dis. 72(4), 552-559 (2013). https://doi.org/10.1136/annrheumdi s-2011-201206

11. Holmes, S.D., Fornaresio, L.M., Miller, C.E., Shuman, D.J., Ad, N.: Development of the Cardiac Surgery Patient Expectations Questionnaire (C-SPEQ). Qual. Life Res. 25(8), 2077-2086 (2016). https://doi.org/10.1007/s11136-016-1243-4

12. Jones, S.M., Lange, J., Turner, J., Cherkin, D., Ritenbaugh, C., Hsu, C., Berthoud, H., Sherman, K.: Development and Validation of the EXPECT Questionnaire: assessing patient expectations of outcomes of complementary and alternative medicine treatments for chronic pain. J. Altern. Complement. Med. 22(11), 936-946 (2016). https://doi.org/10.1089/acm.2016.0242

13. McBain, H., MacKenzie, K., Hancox, J., Ezra, D.G., Adams, G.G., Newman, S.P.: What do patients with strabismus expect post surgery? The development and validation of a questionnaire. Br. J. Ophthalmol. 100(3), 415-419 (2016). https://doi.org/10.1136/ bjophthalmol-2015-307027

14. Patil, V.M., Chakraborty, S., Jithin, T.K., Dessai, S., Sajith Babu, T.P., Raghavan, V., Geetha, M., Kumar, T.S., Biji, M.S., Bhattacharjee, A., Nair, C.: Development and validation of a questionnaire to measure preferences and expectations of patients undergoing palliative chemotherapy: EXPECT questionnaire. Indian J. Cancer 53(2), 339-344 (2016). https://doi.org/10.4103/0019509X.197735

15. Thomas, S., Quirk, L., Blevins, C., Quatrara, B., Letzkus, L.: Incongruence in perceptions: identifying barriers to patient satisfaction in the intensive care unit. Dimens. Crit. Care Nurs. 36(6), 349-354 (2017). https://doi.org/10.1097/DCC.000000000000026 7

16. Pittet, V., Vaucher, C., Froehlich, F., Maillard, M.H., Michetti, P., Swiss IBDCSG: Patient-reported healthcare expectations in inflammatory bowel diseases. PLoS One 13(5), e0197351 (2018). https://doi.org/10.1371/journal.pone.0197351

17. EuroQolGroup: EuroQol—a new facility for the measurement of health-related quality of life. Health Policy 16(3), 199-208 (1990)

18. Janssen, B., Szende, A.: Population Norms for the EQ-5D. In: Szende, A., Janssen, B., Cabases, J. (eds.) Self-Reported Population Health: An International Perspective Based on EQ-5D, Dordrecht, pp. 19-30 (2014)

19. Devlin, N.J., Brooks, R.: EQ-5D and the EuroQol group: past, present and future. Appl. Health Econ. Health Policy 15(2), 127-137 (2017). https://doi.org/10.1007/s40258-017-0310-5

20. Rasanen, P., Roine, E., Sintonen, H., Semberg-Konttinen, V., Ryynanen, O.P., Roine, R.: Use of quality-adjusted life years for the estimation of effectiveness of health care: a systematic literature review. Int. J. Technol. Assess. Health Care 22(2), 235-241 (2006). https://doi.org/10.1017/S0266462306051051

21. Herdman, M., Gudex, C., Lloyd, A., Janssen, M., Kind, P., Parkin, D., Bonsel, G., Badia, X.: Development and preliminary testing of the new five-level version of EQ-5D (EQ-5D-5L). Qual. Life Res. 20(10), 1727-1736 (2011). https://doi.org/10.1007/s 1113 6-011-9903-x

22. Stolk, E., Ludwig, K., Rand, K., van Hout, B., Ramos-Goni, J.M.: Overview, update, and lessons learned from the International EQ5D-5L valuation work: version 2 of the EQ-5D-5L valuation protocol. Value Health 22(1), 23-30 (2019). https://doi.org/10.1016/j. jval.2018.05.010

23. Cox, B., van Oyen, H., Cambois, E., Jagger, C., le Roy, S., Robine, J.M., Romieu, I.: The reliability of the Minimum European Health Module. Int. J. Public Health 54(2), 55-60 (2009). https://doi. org/10.1007/s00038-009-7104-y

24. Van Oyen, H., Bogaert, P., Yokota, R.T.C., Berger, N.: Measuring disability: a systematic review of the validity and reliability of the Global Activity Limitations Indicator (GALI). Arch. Public Health 76, 25 (2018). https://doi.org/10.1186/s13690-018-0270-8 
25. Rencz, F., Gulacsi, L., Drummond, M., Golicki, D., Prevolnik Rupel, V., Simon, J., Stolk, E.A., Brodszky, V., Baji, P., Zavada, J., Petrova, G., Rotar, A., Pentek, M.: EQ-5D in Central and Eastern Europe: 2000-2015. Qual. Life Res. 25(11), 2693-2710 (2016). https://doi.org/10.1007/s11136-016-1375-6

26. Devlin, N.J., Shah, K.K., Feng, Y., Mulhern, B., van Hout, B.: Valuing health-related quality of life: an EQ-5D-5L value set for England. Health Econ. 27(1), 7-22 (2018). https://doi.org/10.1002/ hec. 3564

27. Dolan, P.: Modeling valuations for EuroQol health states. Med. Care 35(11), 1095-1108 (1997)

28. Brouwer, W.B., van Exel, N.J., van Gorp, B., Redekop, W.K.: The CarerQol instrument: a new instrument to measure carerelated quality of life of informal caregivers for use in economic evaluations. Qual. Life Res. 15(6), 1005-1021 (2006). https://doi. org/10.1007/s11136-005-5994-6

29. Suszánszky, É., Konkoly Tege, B., Stauder, A., Kopp, M.: Validation of the Hungarian version of the brief WHO well-being questionnaire (WBI-5) based on the Hungarostudy 2002 national population health study [A WHO jól-lét kérdőív rövidített (WBI5) magyar változatának validálása a Hungarostudy 2002 országos lakossági egészségfelmérés alapján]. Mentálhigiéné és pszichoszomatika 7(3), 247-255 (2006)

30. Topp, C.W., Ostergaard, S.D., Sondergaard, S., Bech, P.: The WHO-5 Well-Being Index: a systematic review of the literature. Psychother. Psychosom. 84(3), 167-176 (2015). https://doi. org/10.1159/000376585

31. Eurostat.: European Health Interview Survey (EHIS wave 2) Methodological manual (2013). https://doi.org/10.2785/43280

32. Hungarian Central Statistical Office: Microcensus.: Data of households and families. Mikrocenzus 2016: A háztartások és családok adatai. Hungarian Central Statistical Office. https://www.ksh.hu/ docs/hun/xftp/idoszaki/mikrocenzus2016/mikrocenzus_2016_6. pdf (2016). Accessed 2 Ap 2019

33. Szende, A., Németh, R.: Health related quality of life of the Hungarian population [A magyar lakosság egészségi állapothoz kapcsolódó éleminősége]. Orv. Hetil. 144(34), 1667-1674 (2003). (Hungarian)

34. Eurostat.: Share of persons aged 16 and over with or without longstanding (chronic) health problems. https://ec.europa.eu/ eurostat/statistics-explained/index.php?title=File:Share_of_perso ns_aged_16_and_over_with_or_without_long-standing_(chron ic)_health_problems,_2016_(\%25)_Health2017.png. Accessed 2 Apr 2019

35. OECD/EU.: Health at a Glance: Europe 2018: State of Health in the EU Cycle. OECD Publishing, Paris (2019)

36. Eurofound.: European Quality of Life Survey 2016. https:// www.eurofound.europa.eu/data/european-quality-of-life-survey. Accessed 2 Apr 2019

37. Hungarian Central Statistical Office.: The standards of living of households. [A háztartások életszínvonala, 2017]. https://www. ksh.hu/docs/hun/xftp/idoszaki/hazteletszinv/hazteletszinv17.pdf. Accessed 2 Apr 2019

38. Hungarian Central Statistical Office.: Yearly expenditures per capita based on COICOP groups, income deciles, regions and settlement type (2010-). [Az egy főre jutó éves kiadások részletezése COICOP-csoportosítás, jövedelmi tizedek (decilisek), régiók és a települések típusa szerint (2010-)]. http://www.ksh.hu/docs/hun/ xstadat/xstadat_eves/i_zhc021a.html?down=1404. Accessed 2 Apr 2019

39. OECD.: Health at a Glance 2017: OECD Indicators. OECD Publishing, Paris (2017)

40. Baji, P., Biro, A.: Adaptation or recovery after health shocks? Evidence using subjective and objective health measures. Health Econ. 27(5), 850-864 (2018). https://doi.org/10.1002/hec.3644

41. Eurostat.: https://ec.europa.eu/eurostat/statistics-explained/index .php/Functional_and_activity_limitations_statistics. Accessed 2 Apr 2019

42. Janssen, M.F., Szende, A., Cabases, J., Ramos-Goni, J.M., Vilagut, G., Konig, H.H.: Population norms for the EQ-5D-3L: a crosscountry analysis of population surveys for 20 countries. Eur. J. Health Econ. (2018). https://doi.org/10.1007/s10198-018-0955-5

43. Rubovszky, C.: Care of elderly people in the family: informal caregivers in Hungary today. [Idősgondozás a családban-a gondozó családtagok helyzete a mai Magyarországon]. Esély 4, 45-70 (2017)

44. OECD.: OECD Economic Survey: Hungary. http://www.oecd.org/ economy/surveys/Hungary-2019-OECD-economic-survey-overv iew.pdf. Accessed 2 Apr 2019

Publisher's Note Springer Nature remains neutral with regard to jurisdictional claims in published maps and institutional affiliations. 